MINERALOGIA, 41, No 1-2: 55-74 (2010)

DOI: 10.2478/v10002-010-0005-0

www.Mineralogia.pl

MineRALOgICAL SOCIETY OF POLAND

Polskie TOWARZYSTWO MINERALOgICZNE

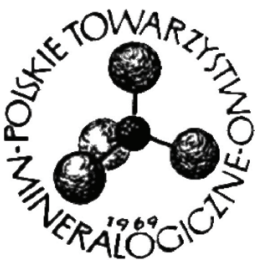

Original paper

\title{
Elemental and mineral inventory of tailing impoundments near Pezinok, Slovakia and possible courses of action for their remediation
}

\author{
Juraj MAJZLAN ${ }^{1 *}$, Björn BRECHT ${ }^{2}$, Bronislava LALINSKÁ ${ }^{3}$, Martin $\mathrm{CHOVAN}^{3}$, \\ Daniel MORAVANSKÝ ${ }^{4}$, Peter UHLÍK ${ }^{5}$ \\ ${ }^{1}$ Institute of Geosciences, Burgweg 11, Friedrich-Schiller University, Jena, D-07749 Germany \\ ${ }^{2}$ Institute of Geosciences, Albertstraße 23b, Albert-Ludwig University, Freiburg, D-79104, Germany \\ ${ }^{3}$ Department of Mineralogy and Petrology, Mlynská dolina G, Comenius University, Bratislava, SK-842 15, \\ Slovakia \\ ${ }^{4}$ Department of Zoology and Anthropology, Nábrežie Mládeže 91, Constantine the Philosopher University, \\ SK-949 74 Nitra, Slovakia \\ ${ }^{5}$ Department of Geology of Mineral Deposits, Mlynská dolina G, Comenius University, Bratislava, SK-842 15, \\ Slovakia \\ *Corresponding author: Juraj.Majzlan@uni-jena.de
}

Received: September 22, 2010

Received in revised form: December 12, 2010

Accepted: January 28, 2010

Available online: February 11, 2011

Abstract. An effective remediation strategy for a polluted site should take the absolute amount of the pollutant(s) into account. Here, we present an elemental budget for $\mathrm{As}, \mathrm{Sb}$ and $\mathrm{Fe}$ in two tailing impoundments of the former $\mathrm{Sb}-\mathrm{Au}$ deposit near Pezinok, Slovakia. The two impoundments contain $5,740 \times 10^{3} \mathrm{~kg} \mathrm{As}, 6,360 \times 10^{3} \mathrm{~kg} \mathrm{Sb}$ and $50,105 \times 10^{3} \mathrm{~kg} \mathrm{Fe}$. An estimated total Au content in the impoundments is $132 \mathrm{~kg}$. The most abundant minerals in the tailings are quartz, illite, and chlorite. The content of carbonates in the tailings is $3.5-10.5 \mathrm{wt} \%$ calcite equivalent and we estimate that the carbonates are sufficiently abundant to buffer the $\mathrm{pH}$ at circumneutral values, up to the point when all pyrite decomposes. The possible courses of action are i) do nothing, ii) build an active barrier to capture the released As and $\mathrm{Sb}$, iii) isolate the impoundments from rain and ground water and iv) use the impoundments as a source of $\mathrm{Sb}$ and redeposit the waste in a safer form. The simplest approach is to do nothing, which seems to be the most likely course of events, given the current economic, political and societal state of the Slovak Republic. Although this action costs nothing in the short term, it may cause significant damage to the environment, especially to the alluvial sediments and associated water resources in the long term.

Key-words: impoundments, Pezinok, remediation, arsenic, antimony 


\section{Introduction}

Arsenic is a common element in many hydrothermal ores, those formed at relatively high temperatures as well as those formed at low temperatures. In the former case, arsenopyrite is the usual carrier; in the latter, orpiment or realgar may be found. Although recovered in large quantities during mining operations, arsenic is not widely used because if its toxicity and remains unwanted. Representative examples of environmental problems caused by intensive mining where undesired by-product is arsenic, are the gold deposits in Mokrsko, Roudný, and Kašperské Hory, Czech Republic (Filippi et al. 2004), Rabbit Lake mine, Canada (Moldovan, Hendry 2005), Ketza River mine, Canada (Paktunc et al. 2003), or El Terronal mine, Spain (Loredo et al. 2003).

Another example of arsenic pollution caused by ore exploitation is Pezinok in Slovakia (geographic coordinates given in Table 1). The ores extracted here were finely ground and flotated between 1906 and 1992, antimony minerals were partially recovered, and the waste mud disposed of in two impoundments. The impoundment sediments are rich in arsenic (As) and antimony ( $\mathrm{Sb}$ ) and the impoundments release a substantial amount of As, Sb, and iron (Fe) into the environment (Flaková et al. 2005; Majzlan et al. 2007). Current research is aimed at proposing a strategy that would curb the dissemination of the pollution in the areas adjoining the two impoundments (Chovan et al. 2006). Such proposals must take into account the total amount of $\mathrm{As}$ and $\mathrm{Sb}$ in the impoundments.

TABLE 1

The geographic coordinates of the boreholes and the As, $\mathrm{Sb}$ and $\mathrm{Fe}$ budgets of the two impoundments in Pezinok

\begin{tabular}{|c|c|c|c|}
\hline & Upper impoundment & & \\
\hline Borehole & PK-7 & PK-6 & PK-8 \\
\hline Latitude (N) & 48.321446 & 48.318175 & 48.318189 \\
\hline Longitude (E) & 17.235585 & 17.238826 & 17.239389 \\
\hline Total As (tons) & 910 & \multicolumn{2}{|c|}{4,830} \\
\hline Total Sb (tons) & 780 & \multicolumn{2}{|c|}{5,580} \\
\hline Total Fe (tons) & 9,725 & \multicolumn{2}{|c|}{40,380} \\
\hline
\end{tabular}

In this work, we investigated the mineralogical and chemical budget of the two impoundments in Pezinok. The principal goal was to determine the total amount of As and $\mathrm{Sb}$ in them and to quantify, as far as possible, the mineral fractions in the sediments. These data should aid in future decisions with regard to remediation or relocation of the impoundment sediments. 


\section{Materials and methods}

The samples were collected from a series of shallow boreholes PK6, PK7, and PK8 (Fig. 1). The particle density (i.e. density of the solid fraction) of the samples was measured by an air-comparison pycnometer. The overall density of the samples was estimated by pressing the powdery samples into cylinders of known volume and mass and weighing the cylinders filled with the sample. The difference between the two density values can be related to the pore volume in the material.

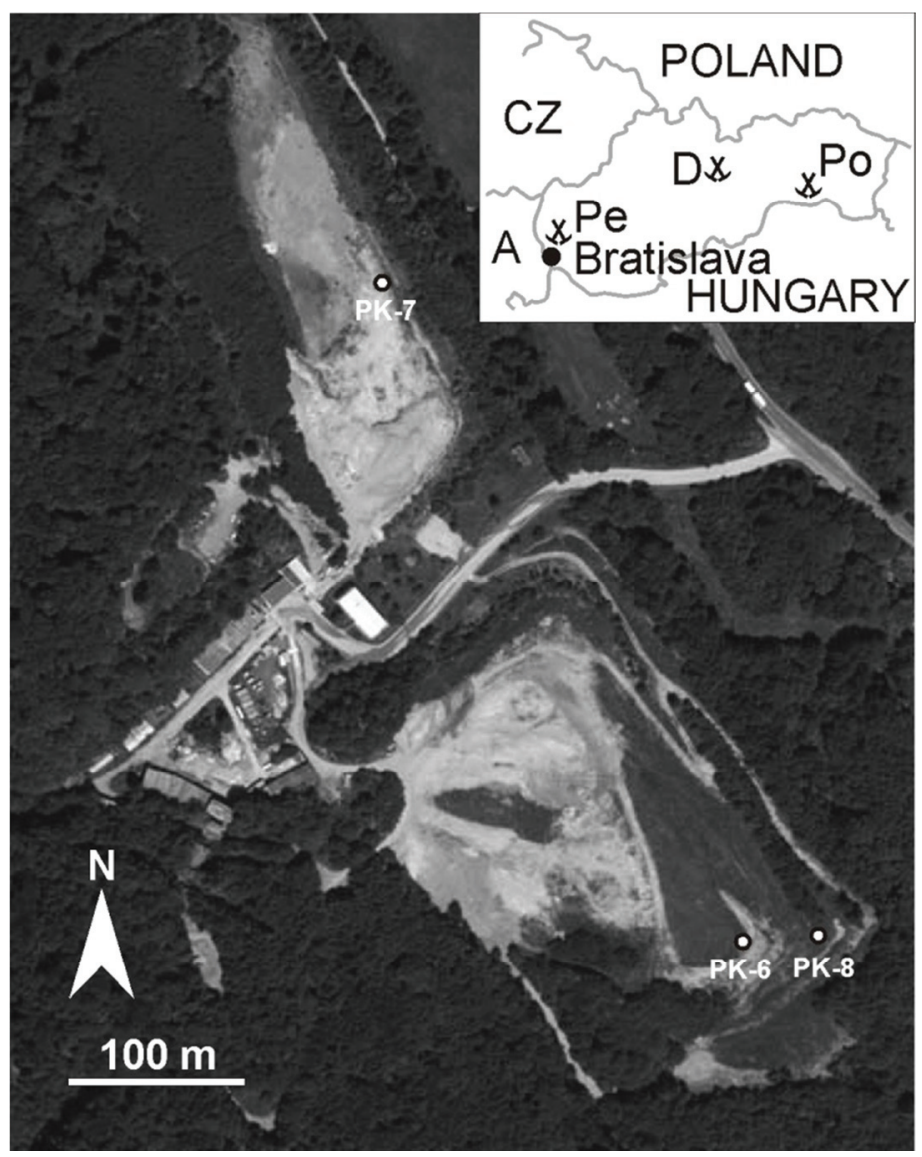

Fig. 1. An aerial photograph of the Pezinok area showing the two impoundments, the former ore-processing plant and the location of the sampling spots for this study. The inset shows the map of Slovakia with the location of the deposits mentioned in the text: Pe - Pezinok, D - Dúbrava,

$$
\text { Po - Poproč }
$$

Heavy minerals were separated from the tailing material by manual panning in water. The resulting concentrates of heavy minerals were dried and divided into heavy and light fractions by separation in bromoform. The heavy fraction was further subdivided into 
a diamagnetic and paramagnetic fraction by passing the samples through a magnetic separator. Each fraction was examined individually under a binocular and the minerals were identified by their physical properties. The abundance of the minerals was quantified by counting a statistically significant number of grains in each sample and normalizing the result to the total number of grains counted.

The X-ray diffraction (XRD) patterns of the bulk tailings were determined using a Bruker D8 Advance diffractometer, employing $\mathrm{Cu} \mathrm{K} \alpha$ radiation, a graphite secondaryradiation monochromator and a scintillation detector. The back-scattered electron (BSE) images of weathering products in the tailings were acquired with a Cameca SX 50 electron microprobe.

We employed sequential extractions BCR (after Rauret et al. 1999) augmented by an additional step to evaluate the mobile fraction of As and $\mathrm{Sb}$. One gram of each sample was successively extracted by chemically stronger aqueous solutions. The procedure divided the extractable metalloids in five fractions. In the first step, the samples were extracted by distilled water $(50 \mathrm{ml})$ and targeted the water soluble fraction (fraction 1). The following steps involved extractants and targeted fractions as follows: $40 \mathrm{ml}$ of $0.11 \mathrm{M}$ acetic acid, ion-exchangeable and carbonate fraction $2 ; 40 \mathrm{ml}$ of $0.1 \mathrm{M} \mathrm{NH}_{2} \mathrm{OH} \cdot \mathrm{HCl}$, reducible fraction 3; $20 \mathrm{ml}$ of $8.8 \mathrm{M} \mathrm{H}_{2} \mathrm{O}_{2}$ and $50 \mathrm{ml}$ of $1 \mathrm{M} \mathrm{NH}_{4} \mathrm{CH}_{3} \mathrm{COO}$, organic-sulfidic fraction 4; digestion by $\mathrm{HNO}_{3}, \mathrm{HF}$, and $\mathrm{HClO}_{4}$, the residual fraction 5 .

The fraction below $2 \mu \mathrm{m}$ was isolated using the sedimentation method and oriented slides were prepared for XRD analysis. These slides were studied in the natural form and after saturation with ethylene glycol ( 8 hours in ethylene glycol vapor at $60^{\circ} \mathrm{C}$ ). The XRD patterns were measured with a PW 1710 Phillips XRD instrument, operating with $\mathrm{Ni}$ filtered $\mathrm{CuK} \alpha$ radiation. The patterns were measured with a step of $0.02^{\circ} 2 \theta$ and a dwell of $1 \mathrm{~s}$ at each step. The reference intensity ratio method was used for a semi quantitative estimate of the abundance of the clay minerals (Moore, Reynolds 1997).

For the bulk chemical analyses, an aliquot of each sample was dried overnight at $105^{\circ} \mathrm{C}$, ground in a motorized agate mortar to a grain size of $<50 \mu \mathrm{m}$, weighed, and digested in a microwave in an aqua regia solution. The solutions were separated from the residua by filtering and analyzed, after appropriate dilution, for $\mathrm{Fe}$, As, and $\mathrm{Sb}$ by flame atomic absorption spectrometry (AAS), using an AAS vario 6 (Analytik Jena). An estimate of the precision of the method, based on repeated measurements of a single sample, is $5 \%$. The residua consisted of quartz with a minor amount of graphite, as shown by X-ray diffraction analysis.

The bulk $\mathrm{pH}$ of the samples was determined in the laboratory with a glass calomel electrode and a Methrom $\mathrm{pH}$ meter. The electrode was calibrated with $\mathrm{pH}$ buffer solutions at $\mathrm{pH} 4$ and 7 . The finely ground material was brought to a suspension in deionized water (1:5 by volume) and the $\mathrm{pH}$ measured after an equilibration time of 30 minutes.

The carbonate content in selected samples was measured from the volume of $\mathrm{CO}_{2}$ released upon contact with $15 \%$ hydrochloric acid. The finely ground samples were weighed out and brought into contact with acid in a tightly sealed glass flask. The $\mathrm{CO}_{2}$ volume was read in a sealed and calibrated glass cylinder. The samples were allowed to outgas for 20-30 minutes, until the reaction stopped and the volume of gas did not increase. No attempt was made to distinguish calcite, dolomite and ankerite by this method. All data 
were recalculated on the basis of equivalent $\mathrm{wt} \%$ of calcite, that is, the amount of calcite that would be responsible for an identical volume of $\mathrm{CO}_{2}$ released during an experiment. A sensitivity analysis carried out on samples with known carbonate (calcite) concentration of $5-10 \%$ has shown that the accuracy of the method is $0.3-0.5$ percentage points. Repeated measurements on the samples of the impoundment sediments have shown that the standard deviation of the measurements is $0.3-1.0$ percentage points, increasing with decreasing carbonate in the samples.

\section{Results and discussion}

The sediments of the impoundments are composed of sand, silt and clay in variable ratios. Larger fragments do occur in some layers but are generally rare. Since 1992, the two tailings impoundments in Pezinok have been covered by 1.5-4.5 meters of overburden of industrial waste (soil mixed with blocks of concrete). The boreholes PK7 and PK8 penetrated into the underlying alluvial sediments. The overlying- and underlying sediments, however, are of little interest for the work presented here.

The profile of the tailings themselves consists of an oxidation zone located directly below the industrial waste, an inactive zone with tailings showing little or no signs of oxidation and an oxidation zone located at the bottom of the impoundments. Although each successive layer of the tailings was exposed to the atmosphere for a certain time, the oxidation processes were too slow to alter them during their short exposure. Therefore, we assume that the top oxidation zone has most likely developed over the last 18 years since the mine operation ceased. This zone is $60-80 \mathrm{~cm}$ thick. Occasional very thin reddish layers within the inactive zone may represent intermittent breaks in the mine operation when the uppermost tailing layer was exposed to the atmosphere for a longer time. The oxidation at the bottom of the impoundments is driven by the surface waters which flow along the base of the impoundments. The bottom oxidation zone is $\sim 100 \mathrm{~cm}$ thick. The tailings lie directly on the alluvial sediments. The unoxidized sediments have a gray to greenish-gray or brownish color. The visual observation of the degree of oxidation correlates roughly with the Eh values measured in the sediments (Figs. 2-4).

The $\mathrm{pH}$ of the aqueous solutions sampled in the boreholes or of those discharged from the impoundments is 7.0 \pm 0.6 (Majzlan et al. 2007), despite the oxidation and decomposition of the sulfides. The $\mathrm{pH}$ values of the sediments are also circumneutral and are graphically shown in the profiles of the individual boreholes (Figs. 2-4). The acidity generated by the decomposing sulfides is neutralized by the abundant carbonates from the ores. The impoundments in Pezinok are therefore specific because they hold neutral mine drainage (NMD). The occurrence of NMD is less common than acid-mine drainage (AMD) but not unique to Pezinok (Heikkinen et al. 2009; Lindsay et al. 2009). 


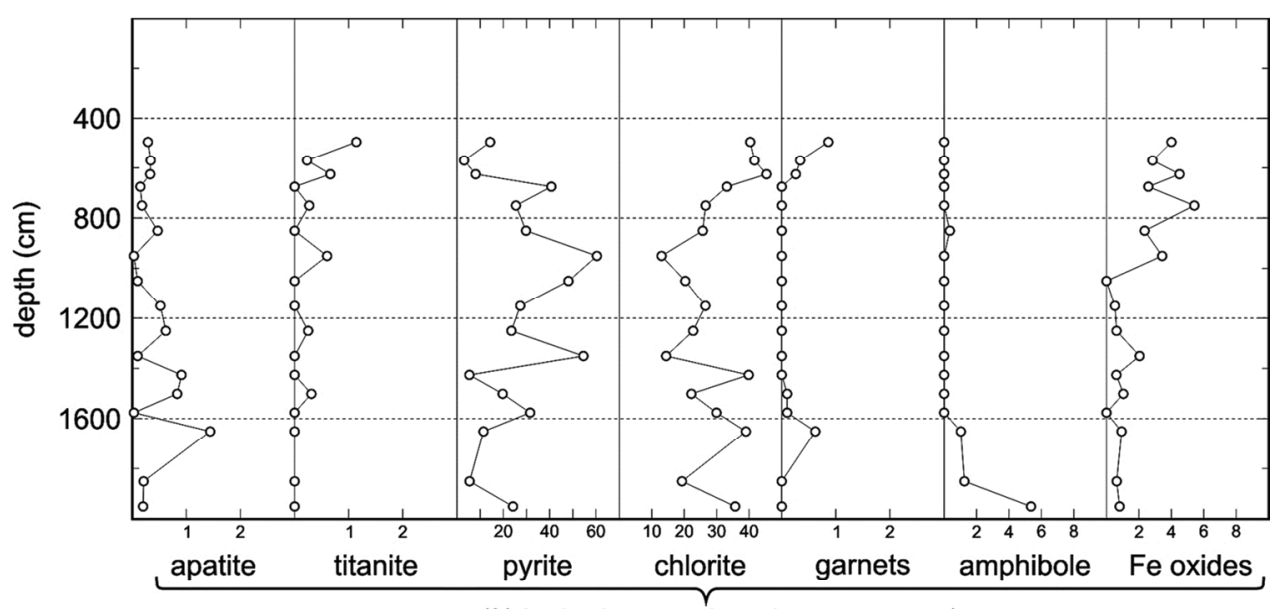

(\% in the heavy mineral concentrates)
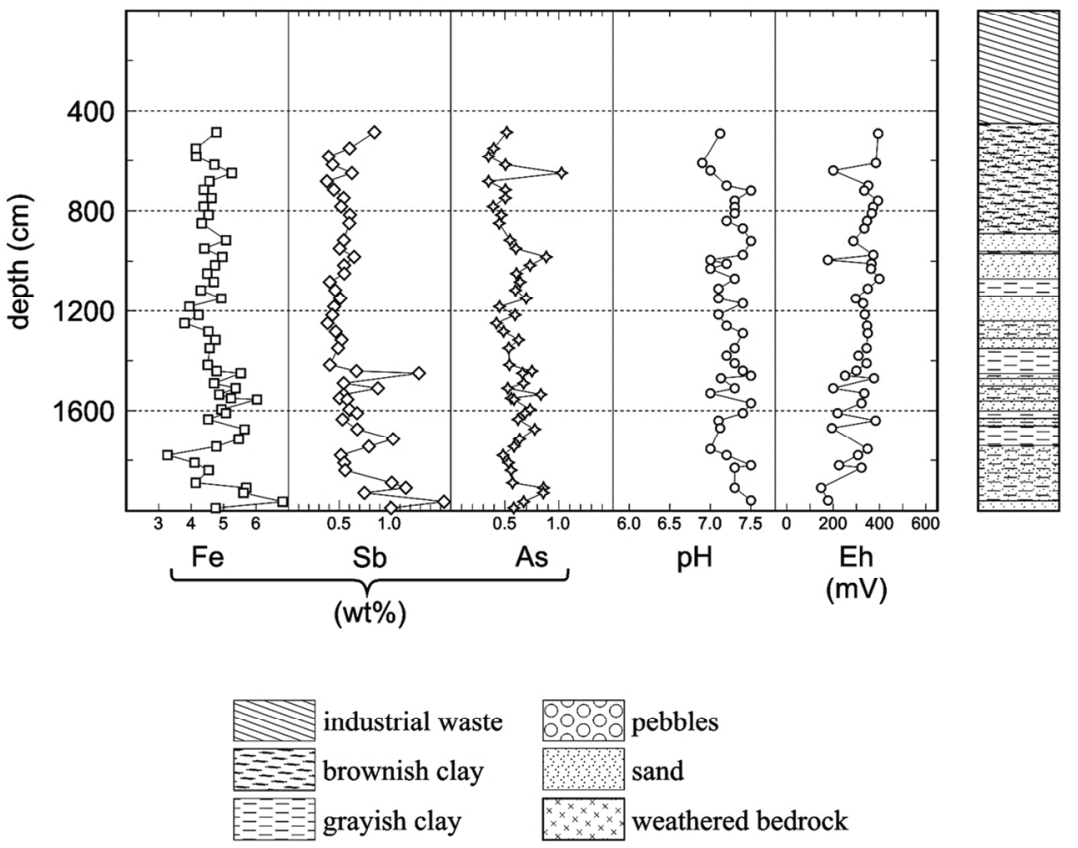

Fig. 2. Physico-chemical parameters, and contents of selected elements and minerals in the heavy concentrates, in borehole PK6. The lower-right panel shows the profile of the borehole with an indication of the character of the sediments 

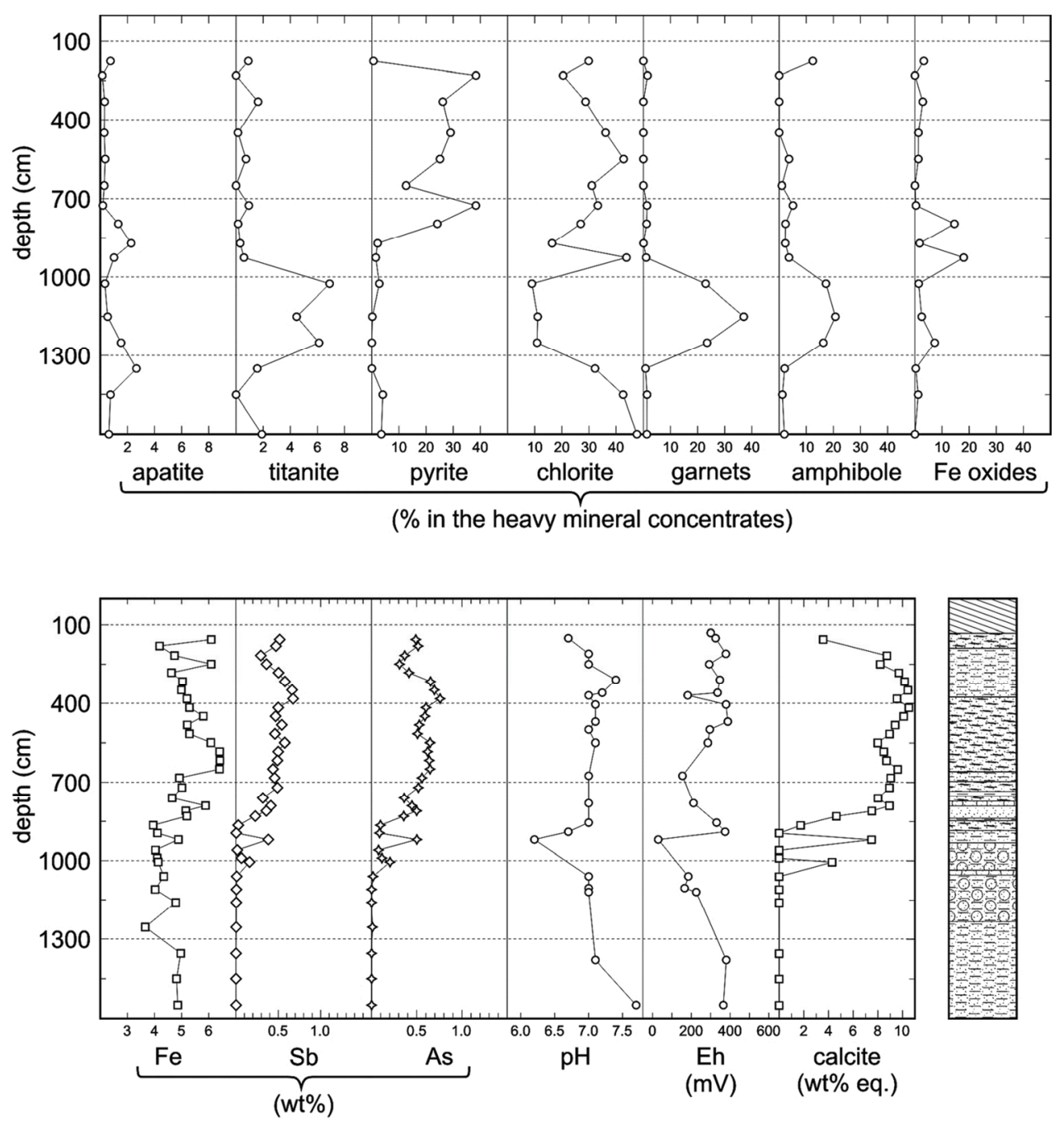

Fig. 3. Physico-chemical parameters, and contents of selected elements and minerals in the heavy concentrates, in borehole PK7. The lower-right panel shows the profile of the borehole with an indication of the character of the sediments. Profile fill patterns same as in Fig. 2 


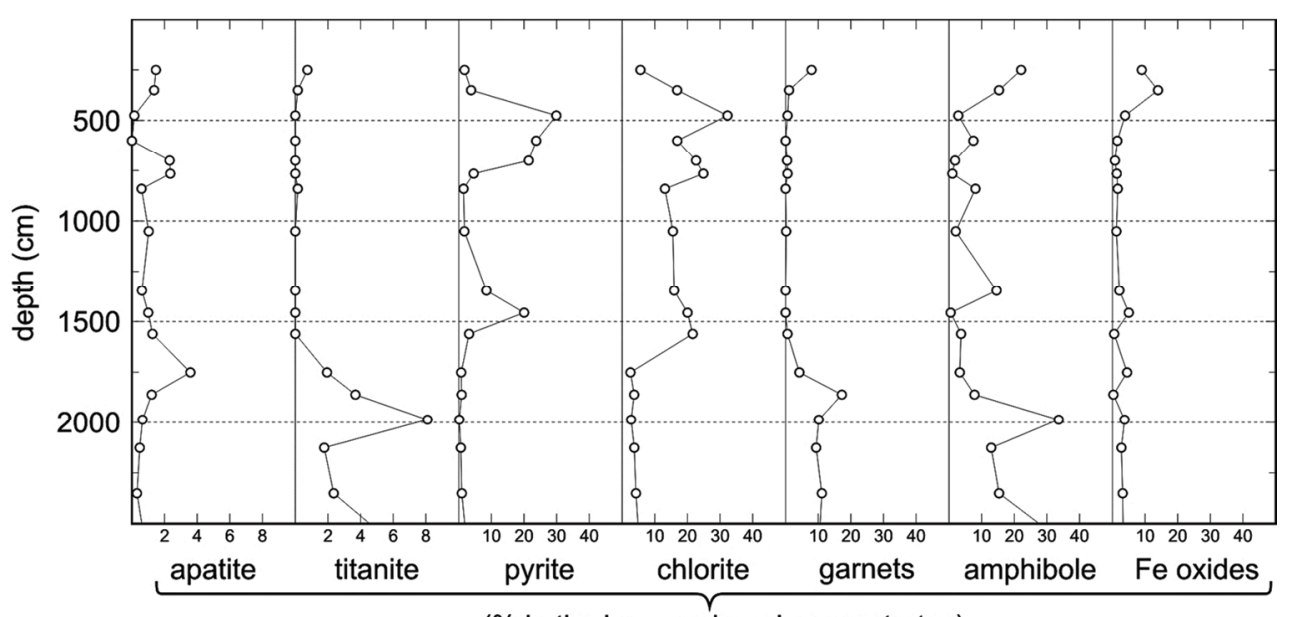

(\% in the heavy mineral concentrates)
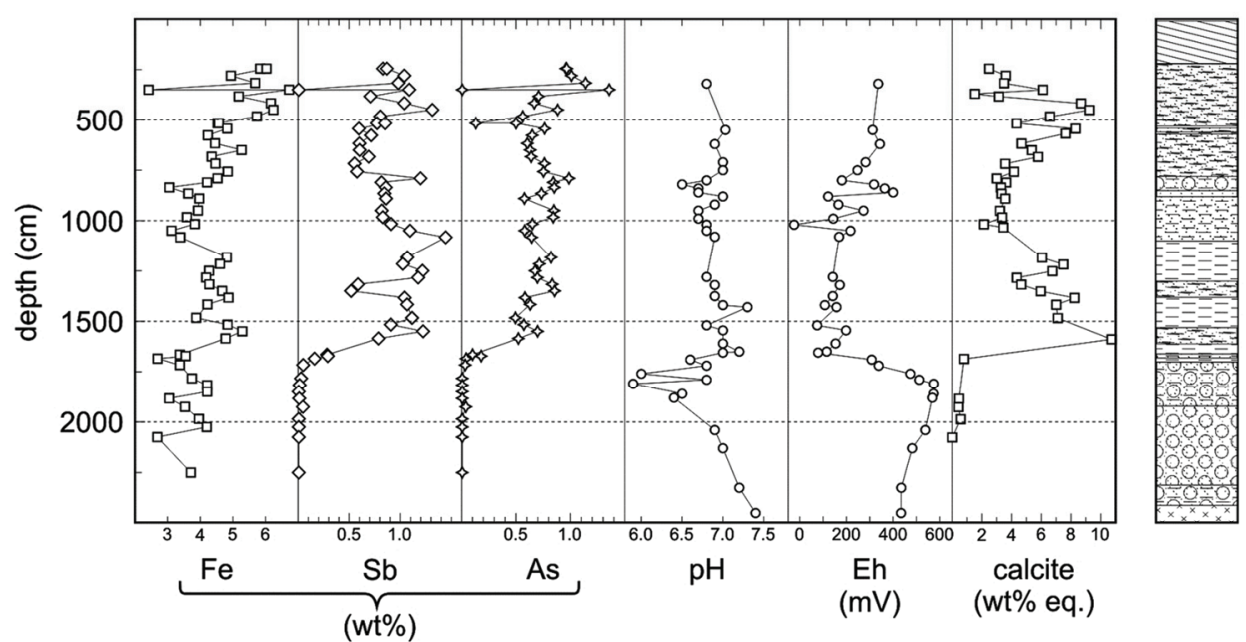

Fig. 4. Physico-chemical parameters, and contents of selected elements and minerals in the heavy concentrates, in borehole PK8. The lower-right panel shows the profile of the borehole with an indication of the character of the sediments. Profile fill patterns same as in Fig. 2

\subsection{Concentration of $\mathrm{Fe}$ and metalloids in the tailings}

On average, the tailings contain $4.77 \pm 0.80(1 \sigma) \mathrm{wt} \% \mathrm{Fe}, 0.66 \pm 0.30 \mathrm{wt} \% \mathrm{Sb}$, and $0.60 \pm 0.21 \mathrm{wt} \%$ As (average of 118 analyses; see Tables 2-4). In an extensive estimate of the element budget of the impoundments after the mine shutdown, Pomorský et al. (2002) determined that the tailings contain $0.58 \mathrm{wt} \% \mathrm{Sb}, 0.59 \mathrm{wt} \%$ As and $1.12 \mathrm{~g} \mathrm{Au} / \mathrm{t}$. 
TABLE 2

Contents of $\mathrm{Fe}, \mathrm{Sb}$ and $\mathrm{As}$ in the tailings samples in borehole PK6

\begin{tabular}{cccccccc}
\hline $\begin{array}{c}\text { Depth } \\
(\mathrm{cm})\end{array}$ & $\mathrm{Fe}$ & $\begin{array}{c}\mathrm{Sb} \\
(\mathrm{mg} / \mathrm{kg})\end{array}$ & $\begin{array}{c}\text { As } \\
\text { ( }\end{array}$ & $\begin{array}{c}\text { Depth } \\
(\mathrm{cm})\end{array}$ & & $\begin{array}{c}\mathrm{Sb} \\
(\mathrm{mg} / \mathrm{kg})\end{array}$ \\
\hline $470-500$ & 47760 & 8468 & 5173 & $1300-1333$ & 47440 & 5223 & 6276 \\
$533-566$ & 41440 & 6016 & 3969 & $1333-1366$ & 45660 & 4879 & 5355 \\
$566-600$ & 41520 & 3944 & 3485 & $1400-1433$ & 45100 & 4077 & 5415 \\
550 & 48520 & 9736 & 4516 & $1433-1450$ & 47820 & 6702 & 7502 \\
$600-633$ & 47120 & 4350 & 5052 & 1450 & 55260 & 12857 & 6628 \\
650 & 52500 & 6246 & 10240 & $1480-1500$ & 47040 & 5433 & 6733 \\
$666-700$ & 45600 & 3779 & 3488 & 1510 & 53660 & 8812 & 5269 \\
$700-733$ & 43880 & 4465 & 5049 & $1520-1550$ & 48600 & 5436 & 8322 \\
$733-766$ & 46280 & 5425 & 5042 & 1550 & 52240 & 5035 & 5585 \\
$766-800$ & 43860 & 5185 & 3918 & $1550-1560$ & 60260 & 5799 & 5841 \\
$800-833$ & 45320 & 6045 & 4673 & $1590-1600$ & 49300 & 5994 & 7323 \\
$833-866$ & 43220 & 5989 & 4480 & $1600-1620$ & 50680 & 6754 & 6857 \\
$900-933$ & 50720 & 5451 & 5475 & $1620-1650$ & 45200 & 5319 & 6214 \\
$933-966$ & 44040 & 5041 & 6020 & $1650-1700$ & 56400 & 6773 & 7757 \\
$966-1000$ & 49580 & 6462 & 8824 & $1700-1730$ & 54620 & 10311 & 6362 \\
$1000-1033$ & 47300 & 5465 & 7327 & $1730-1760$ & 47720 & 7922 & 5850 \\
$1033-1066$ & 44940 & 5495 & 6067 & $1760-1800$ & 32680 & 5163 & 4828 \\
$1066-1100$ & 46960 & 4071 & 6406 & $1800-1820$ & 41020 & 5490 & 5344 \\
$1160-1133$ & 42960 & 4593 & 5976 & $1820-1860$ & 45360 & 5589 & 5574 \\
$1133-1166$ & 49280 & 5098 & 6969 & $1880-1900$ & 41380 & 10178 & 5708 \\
$1166-1200$ & 39440 & 4491 & 4502 & $1900-1920$ & 56940 & 11561 & 8572 \\
$1200-1233$ & 42260 & 4318 & 5940 & $1930-1950$ & 56100 & 7484 & 8547 \\
$1233-1266$ & 37940 & 3836 & 4214 & $1950-1980$ & 68180 & 15326 & 6736 \\
$1266-1300$ & 45280 & 4637 & 4878 & $1980-2000$ & 47500 & 10108 & 5819 \\
\hline & & & & & & & \\
\hline
\end{tabular}


TABLE 3

Density and concentration of $\mathrm{Fe}, \mathrm{Sb}$, As, and calcite in the tailing impoundment samples in the borehole PK7

\begin{tabular}{|c|c|c|c|c|c|c|}
\hline $\begin{array}{l}\text { Depth } \\
(\mathrm{cm})\end{array}$ & $\begin{array}{c}\text { Total } \\
\text { density }\end{array}$ & $\begin{array}{l}\text { Particle } \\
\text { density }\end{array}$ & As & $\begin{array}{c}\mathrm{Sb} \\
(\mathrm{mg} / \mathrm{kg})\end{array}$ & $\mathrm{Fe}$ & $\begin{array}{c}\text { Calcite } \\
\text { (eq. wt.\%) }\end{array}$ \\
\hline $150-160$ & n.d. & n.d. & 4884 & 5161 & 60890 & 3.57 \\
\hline $160-200$ & 1.56 & 3.35 & 5142 & 4713 & 41840 & n.d. \\
\hline $200-233$ & 1.59 & 3.25 & 3662 & 2932 & 47350 & 8.73 \\
\hline $233-266$ & 1.54 & 2.91 & 3087 & 3603 & 60860 & 8.19 \\
\hline $266-299$ & 1.61 & 3.16 & 4131 & 5016 & 46225 & 9.7 \\
\hline $300-333$ & 1.56 & 3.04 & 6510 & 5773 & 50290 & 10.17 \\
\hline $333-366$ & 1.67 & 2.88 & 6938 & 6617 & 49870 & 10.43 \\
\hline $366-400$ & 1.6 & 3.07 & 7575 & 6735 & 51936 & 9.55 \\
\hline $400-433$ & 1.61 & 2.77 & 6011 & 4982 & 52850 & 10.51 \\
\hline $433-466$ & 1.65 & 3.11 & 5891 & 4674 & 57970 & 10.09 \\
\hline $466-499$ & 1.55 & 2.83 & 5272 & 5409 & 52050 & 9.4 \\
\hline $500-533$ & 1.7 & 2.96 & 5074 & 4599 & 52854 & 8.95 \\
\hline $533-566$ & 1.64 & 2.94 & 6459 & 5752 & 60740 & 7.99 \\
\hline $566-600$ & 1.61 & n.d. & 6196 & 4978 & 63982 & 8.48 \\
\hline $600-633$ & 1.67 & 2.97 & 6379 & 4887 & 64092 & 8.7 \\
\hline 633-666 & 1.62 & 3.03 & 6459 & 4364 & 63922 & 9.61 \\
\hline $666-700$ & 1.59 & 2.78 & 5566 & 4562 & 49150 & 9.04 \\
\hline $700-740$ & 1.68 & 2.9 & 5166 & 4887 & 50090 & 8.94 \\
\hline $740-780$ & 1.57 & 2.89 & 3601 & 3174 & 46480 & 8.01 \\
\hline $780-800$ & 1.14 & 2.94 & 4462 & 4113 & 58780 & 8.94 \\
\hline $800-820$ & 1.5 & 2.87 & 4986 & 3578 & 51507 & 7.51 \\
\hline $820-840$ & 1.66 & 2.84 & 3556 & 2273 & 51886 & 4.64 \\
\hline $840-890$ & 1.38 & 2.74 & 974 & 273 & 39481 & 1.74 \\
\hline $890-900$ & 1.46 & 2.44 & 874 & $<100$ & 41050 & 0 \\
\hline $900-940$ & 1.62 & 2.81 & 5006 & 3816 & 48771 & 7.49 \\
\hline $940-980$ & 0.93 & 2.6 & 764 & 156 & 40319 & 0 \\
\hline $980-1000$ & 1.55 & 2.85 & 1141 & 645 & 40968 & 0 \\
\hline $1000-1010$ & 1.63 & 2.72 & 2035 & 1602 & 41320 & 4.29 \\
\hline $1020-1100$ & 1.53 & 2.83 & 151 & $<100$ & 43390 & 0 \\
\hline $1100-1120$ & 1.72 & 2.81 & $<100$ & $<100$ & 40220 & 0 \\
\hline $1120-1200$ & 1.71 & 2.81 & $<100$ & $<100$ & 47810 & 0 \\
\hline $1200-1310$ & 1.73 & 2.86 & $<100$ & $<100$ & 36550 & 0 \\
\hline $1310-1400$ & 1.46 & 3.42 & $<100$ & $<100$ & 49641 & 0 \\
\hline $1400-1500$ & 1.54 & 2.75 & $<100$ & $<100$ & 48090 & 0 \\
\hline $1500-1600$ & 1.42 & 2.75 & $<100$ & $<100$ & 48540 & 0 \\
\hline $1600-1700$ & 1.55 & 2.8 & $<100$ & $<100$ & 49900 & 0 \\
\hline
\end{tabular}


TABLE 4

Contents of $\mathrm{Fe}, \mathrm{Sb}$ and As in the tailings samples in borehole PK8

\begin{tabular}{|c|c|c|c|c|c|c|c|}
\hline $\begin{array}{l}\text { Depth } \\
(\mathrm{cm})\end{array}$ & $\mathrm{Fe}$ & $\begin{array}{c}\mathrm{Sb} \\
(\mathrm{mg} / \mathrm{kg})\end{array}$ & As & $\begin{array}{l}\text { Depth } \\
(\mathrm{cm})\end{array}$ & $\mathrm{Fe}$ & $\begin{array}{c}\mathrm{Sb} \\
(\mathrm{mg} / \mathrm{kg})\end{array}$ & As \\
\hline $230-260$ & 60260 & 8669 & 9645 & 1066-1099 & 33860 & 14425 & 6429 \\
\hline $260-300$ & 49360 & 10376 & 10079 & 1166-1199 & 48100 & 10668 & 8209 \\
\hline $300-333$ & 56800 & 9798 & 11377 & $1200-1230$ & 46020 & 10240 & 7129 \\
\hline 350 & 24180 & $<100$ & $<100$ & $1233-1266$ & 42680 & 12151 & 6743 \\
\hline $333-366$ & 67220 & 10853 & 13546 & $1266-1300$ & 41780 & 11734 & 6954 \\
\hline 366-399 & 51780 & 7078 & 7069 & $1300-1333$ & 42740 & 5855 & 8316 \\
\hline $400-433$ & 61620 & 10378 & 6669 & $1333-1366$ & 46700 & 5181 & 8538 \\
\hline $433-466$ & 62380 & 13120 & 8813 & $1366-1400$ & 48620 & 10403 & 5815 \\
\hline 466-499 & 57320 & 8039 & 5616 & $1400-1433$ & 42180 & 10648 & 6294 \\
\hline $500-533$ & 45280 & 7720 & 1297 & $1466-1500$ & 38720 & 11136 & 4941 \\
\hline $500-533$ & 45660 & 8502 & 4994 & $1500-1533$ & 48360 & 9064 & 5718 \\
\hline $533-553$ & 48240 & 5948 & 7619 & $1533-1566$ & 52860 & 12216 & 6971 \\
\hline $533-600$ & 42300 & 7138 & 6479 & $1560-1610$ & 47740 & 7863 & 5210 \\
\hline $600-633$ & 44500 & 6002 & 6032 & $1660-1670$ & 33700 & 2826 & 999 \\
\hline $633-666$ & 52640 & 6020 & 6290 & $1668-1676$ & 35480 & 2902 & 1790 \\
\hline $666-699$ & 43480 & 6909 & 6383 & $1670-1700$ & 26920 & 1607 & 406 \\
\hline $700-733$ & 44620 & 5528 & 7604 & $1700-1733$ & 33720 & 486 & 322 \\
\hline $733-780$ & 48400 & 5766 & 7512 & $1766-1800$ & 37420 & 280 & $<100$ \\
\hline $780-800$ & 45280 & 11955 & 9857 & $1800-1833$ & 42080 & 140 & $<100$ \\
\hline $800-820$ & 42080 & 8148 & 8419 & $1833-1866$ & 42100 & $<100$ & $<100$ \\
\hline $820-850$ & 30480 & 8569 & 8506 & $1866-1900$ & 30460 & 103 & $<100$ \\
\hline $850-880$ & 36300 & 8427 & 7329 & $1900-1950$ & 35300 & 461 & 378 \\
\hline $880-900$ & 39660 & 8590 & 5768 & $1970-2000$ & 39560 & $<100$ & $<100$ \\
\hline $933-966$ & 39280 & 8173 & 8476 & $2000-2050$ & 41960 & $<100$ & $<100$ \\
\hline $966-999$ & 35880 & 8284 & 8410 & $2050-2100$ & 26840 & $<100$ & $<100$ \\
\hline $1000-1033$ & 38300 & 9080 & 6496 & $2200-2300$ & 37080 & $<100$ & $<100$ \\
\hline $1033-1066$ & 31180 & 10928 & 5794 & & & & \\
\hline
\end{tabular}

There are no significant minima or maxima in the As or Sb concentrations within the tailings profiles. The maximum $\mathrm{Sb}$ concentration measured is $1.53 \mathrm{wt} \%$; that of As is $1.35 \mathrm{wt} \%$. At the base of the impoundments, the concentration of both metalloids decreases 
sharply and is essentially zero in the underlying alluvial or eluvial sediments (Figs. 3, 4). This observation suggests that the impoundments do not contaminate the alluvial sediments directly under them. The toxic weathering products are released along the downstream flanks of the impoundments and carried further away by surface- and ground water (Majzlan et al. 2007).

\subsection{Mobile pools of the pollutants within the tailings}

The mobile pool of metals and metalloids causes the environmental risk and therefore drives the remedial decision making. There are a number of tests available to assess the mobility of the pollutants in a given waste form, for example those of the US Environmental Protection Agency (US EPA) or the lowest chronic values (Suter, Tsao 1996). The samples used for the sequential extraction in this study were unoxidized tailings which represent the dominant material within the impoundments. The results (Table 5) show that less than $1 \%$ of As and $4-8 \%$ of Sb is water-soluble. Antimony was not released into the ion-exchangeable and carbonate fraction at all. As expected, the highest amounts of $\mathrm{As}$ and $\mathrm{Sb}$ are found in the residual fraction because the unoxidized tailings still contain abundant primary sulfides. These results can be compared to the chemical analyses of waters sampled from the boreholes (Majzlan et al. 2007). The borehole waters have $\mathrm{pH}$ values of $7.0 \pm 0.6$, average concentrations of major ions $\left(\mathrm{Na}, \mathrm{Ca}, \mathrm{Cl}, \mathrm{SO}_{4}\right)$, and contain up to $80 \mathrm{mg} \mathrm{As} / 1$ and up to $2.5 \mathrm{mg} \mathrm{Sb} / \mathrm{l}$. Therefore, the borehole waters, as an extractant, correspond most closely to the distilled water used in the step 1 of our extractions. The measured concentrations in step 1 (27-91 $\mathrm{mg}$ As/ $\mathrm{kg}$ sample released) correspond to concentrations of $0.5-1.8 \mathrm{mg} \mathrm{As} / 1$ in the extracted solution. When compared to the $80 \mathrm{mg}$ $\mathrm{As} / 1$ of the borehole waters, it is clear that the sequential extractions are a good tool for

TABLE 5

The amounts of As and $\mathrm{Sb}$ released from the samples in the successive steps of the sequential extraction

\begin{tabular}{|c|c|c|c|c|c|c|c|c|c|c|c|c|}
\hline \multirow{3}{*}{$\begin{array}{c}\text { Borehole } \\
\text { Depth }\end{array}$} & \multicolumn{4}{|c|}{ PK-6 } & \multicolumn{4}{|c|}{ PK-7 } & \multicolumn{4}{|c|}{ PK-8 } \\
\hline & \multicolumn{4}{|c|}{$1300-1333 \mathrm{~cm}$} & \multicolumn{4}{|c|}{$780-800 \mathrm{~cm}$} & \multicolumn{4}{|c|}{$780-800 \mathrm{~cm}$} \\
\hline & $\begin{array}{c}\mathrm{mg} \\
\mathrm{As} / \mathrm{kg}\end{array}$ & $\%$ & $\begin{array}{c}\mathrm{mg} \\
\mathrm{Sb} / \mathrm{kg}\end{array}$ & $\%$ & $\begin{array}{c}\mathrm{mg} \\
\mathrm{As} / \mathrm{kg}\end{array}$ & $\%$ & $\begin{array}{c}\mathrm{mg} \\
\mathrm{Sb} / \mathrm{kg}\end{array}$ & $\%$ & $\begin{array}{c}\mathrm{mg} \\
\mathrm{As} / \mathrm{kg}\end{array}$ & $\%$ & $\begin{array}{c}\mathrm{mg} \\
\mathrm{Sb} / \mathrm{kg}\end{array}$ & $\%$ \\
\hline Fraction 1 & 38.2 & 0.6 & 424 & 7.7 & 26.9 & 0.6 & 242 & 6 & 90.9 & 0.8 & 353 & 4.1 \\
\hline Fraction 2 & 146 & 2.3 & $<0.1$ & 0 & 229 & 4.7 & $<0.1$ & 0 & 233 & 2.1 & $<0.1$ & 0 \\
\hline Fraction 3 & 908 & 14.5 & 784 & 14.2 & 1364 & 28.1 & 323 & 8 & 5700 & 52.7 & 612 & 7 \\
\hline Fraction 4 & 2095 & 33.5 & 77 & 1.4 & 1645 & 33.9 & 27.9 & 0.7 & 1535 & 14.1 & 50.7 & 0.6 \\
\hline Fraction 5 & 3075 & 49.1 & 4238 & 76.7 & 1586 & 32.7 & 3430 & 85.3 & 3291 & 30.3 & 7694 & 88.3 \\
\hline
\end{tabular}

The values in $\%$ represent the portion of the metalloid released with respect to the sum from all steps of the extraction. 
comparison among samples from a single locality or suitable for legislative purposes but give no reliable picture of the amount of As which can be actually transferred into a solution under given conditions. The sequential extractions provide an instantaneous measurement of the achievable concentrations and do not take the kinetics of element release into account. The active discharge of material with enormous As concentrations (up to $28.3 \mathrm{wt} \%$ of $\mathrm{As}_{2} \mathrm{O}_{5}$ ) from the impoundments in Pezinok shows that the mobile pool of pollutants is large and difficult to assess using short-term sequential extractions.

\subsection{Bulk mineralogy of the tailings}

Quartz, illite, and a sheet silicate with the basal interplanar spacing of $14 \AA$, either smectite or chlorite, prevail in all X-ray diffraction patterns collected from the tailings material. Other minerals identified in the XRD patterns are albite, $\mathrm{Ca}-\mathrm{Mg}$ amphibole (tremolite), calcite and Fe-dolomite, pyrite and arsenopyrite. Careful optical examination of the heavy mineral concentrates of the tailings material revealed the presence of chlorite, pyrite and $\mathrm{Fe}$ oxides as the major constituents of this fraction (Figs. 2-4). Other minerals identified, either in minor or trace quantities, were sulfides other than pyrite, apatite, titanite, micas, amphiboles, carbonates, epidote-zoisite, garnets, ilmenite, monazite, xenotime, and magnetite. In a number of cases, a clear assignment of a single grain to a mineral or mineral group listed above could not be made, e.g. the micas of the biotite group and chlorite because at least part of the chlorite originated by hydrothermal alteration of biotite (Moravanský et al. 2001). A small amount of quartz and feldspars which was not completely separated from the heavy fraction was found in each concentrate fraction.

The boreholes PK7 and PK8 penetrated into the underlying alluvial sediments and provide information about the contrasting mineralogy of the tailings and the alluvial sediments. At the base of the impoundments, the content of chlorite and pyrite in the heavy fraction diminishes sharply (Figs. 3, 4). The transition into the alluvial sediments is marked by an increase of the content of apatite, titanite, garnets, and amphiboles. Some of these minerals were probably derived from the granitoid rocks which are abundant in the wider area of the deposit. Amphiboles may have come from the amphibolites which also occur there. Interestingly, the amount of chlorite increases with depth in the alluvial sediments of borehole PK7. A possible explanation for this observation could be the presence of weathered chlorite phyllites which are known to occur in the Pezinok area.

Another noteworthy feature is the lack of pyrite in borehole PK8, section 9-13 m. The low content of pyrite correlates well with the diminished concentration of carbonates measured by the released $\mathrm{CO}_{2}$ (Fig. 4). Though this section $(9-13 \mathrm{~m})$ is made predominantly or almost exclusively of clays, the contents of As and $\mathrm{Sb}$ in it do not fall below the values seen in other sections of this or the other boreholes. The relationship of the metalloids to the clays remains an open question.

\subsection{Clay minerals}

Several samples were selected for identification of the minerals in the clay fraction $(<2 \mu \mathrm{m})$. We must point out that these are only those minerals with particle sizes less than $2 \mu \mathrm{m}$ and which can be separated and dispersed in an aqueous suspension. Nanosized 
ferrihydrite, goethite and tripuhyite (identified by Majzlan et al. 2011) meet the first requirement but cannot be easily dispersed and are, therefore, not easily detected by this method. The minerals targeted by this procedure are mostly phyllosilicates.

The dispersable $<2 \mu \mathrm{m}$ fraction of most of the studied samples is dominated by illite (Table 6). The second most common phyllosilicate is chlorite. Traces of the expandable phyllosilicate smectite are present in traces in some samples. There are also traces of nonphyllosilicate minerals or materials, e.g., quartz and feldspars. The elevated background in the XRD patterns implies the presence of organic or other X-ray amorphous materials, possibly X-ray amorphous iron oxides.

TABLE 6

Abundances (in \%) of minerals in the fraction $<2 \mu \mathrm{m}$

\begin{tabular}{ccccc}
\hline $\begin{array}{c}\text { Sample } \\
\text { (drillhole, depth) }\end{array}$ & Chlorite & Illite & Smectite & Quartz \\
\hline PK6, 1433-1450 & 13 & 81 & traces & 6 \\
PK6, 1600-1620 & 17 & 76 & traces & 8 \\
PK6, 1650-1700 & 16 & 76 & 0 & 8 \\
PK6, 1700-1730 & 20 & 74 & 0 & 6 \\
PK7, 700-740 & 16 & 84 & 0 & traces \\
PK7, 1400-1500 & 76 & 15 & 9 & 0 \\
PK8, 900-933 & 22 & 71 & traces & 7 \\
PK8, 1100-1133 & 9 & 83 & 0 & 9 \\
PK8, 1133-1166 & 13 & 83 & 0 & 5 \\
PK8, 1433-1466 & 14 & 79 & 0 & 7 \\
PK8, 1610-1660 & 19 & 77 & traces & 4 \\
PK8, 1733-1766 & 28 & 50 & 18 & 4 \\
\hline
\end{tabular}

Two samples from the underlying alluvial sediments have different compositions. Chlorite dominates in PK7, at the $1400-1500 \mathrm{~cm}$ level. In PK8, at 1733-1766 cm, illite accounts for $50 \%$ of the separated material, and smectite is much more abundant than in the other samples. This sample also contains a substantial amount of chlorite.

\subsection{Ore minerals and their weathering products}

A detailed mineralogical study of the ore minerals and their weathering products (Majzlan et al. 2011) showed the presence of pyrite, arsenopyrite, gudmundite, berthierite and stibnite as the primary ore minerals; the weathering products comprise goethite, tripuhyite, siderite, and As-rich hydrous ferric oxide, either as rims on the primary sulfide minerals or individual grains (Fig. 5). Because of their minor proportions in the waste or their poor crystallinity, many of these minerals were not seen in the XRD data. During the optical examination, goethite, hydrous ferric oxide and tripuhyite were described as $\mathrm{Fe}$ 
oxides because they are alike in their macroscopic appearance. An exhaustive study of these products, using a suite of microtechniques (electron microprobe, scanning and transmission electron microscopy, micro X-ray diffraction) was presented by Majzlan et al. (2011). A detailed description of the weathering products will not be repeated in this paper.
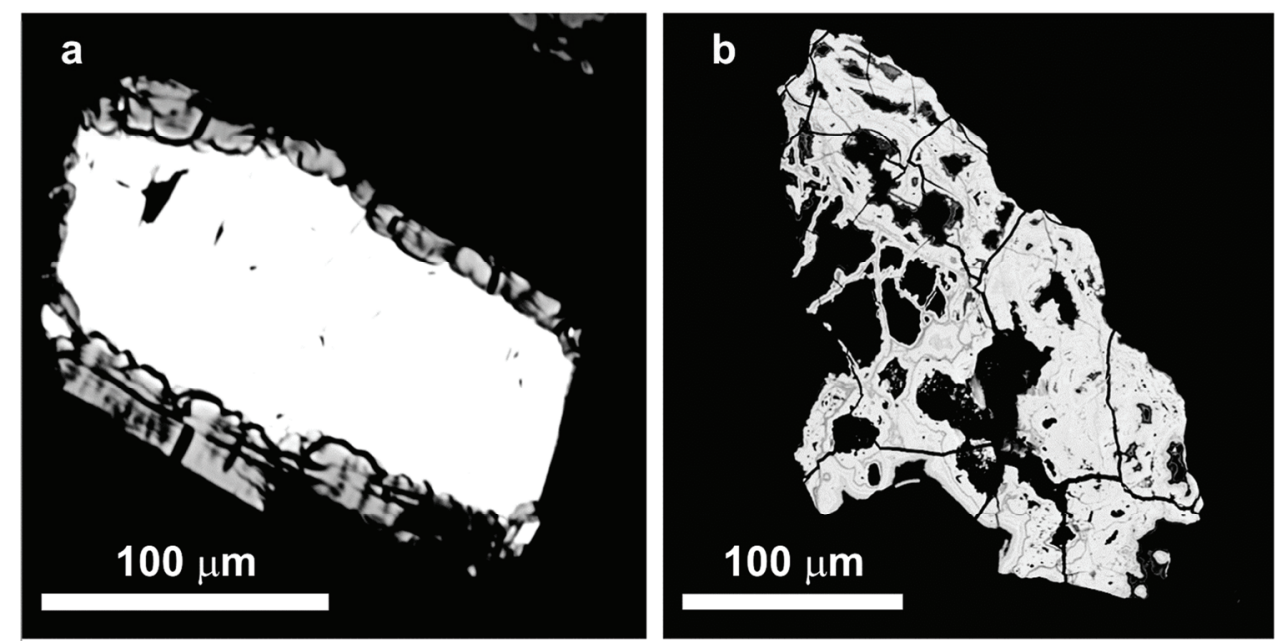

Fig. 5. BSE images of a) arsenopyrite crystals with weathering rims; b) a Sb-Fe-rich grain from the tailings in Pezinok. The chemical and mineralogical composition of many such rims and grains was reported by Majzlan et al. (2011)

\subsection{Carbonates and their neutralization capacity}

The neutral nature (in terms of $\mathrm{pH}$ ) of the mine drainage in Pezinok, as mentioned above, is caused by the neutralization capacity of the omnipresent carbonates. Because this group of minerals plays a decisive role in controlling the $\mathrm{pH}$ of the impoundments, and therefore the fate of elements in them, we quantified the abundance of carbonates by a chemical method. In the tailings of borehole PK7, the carbonates represent $3.5-10.5 \mathrm{wt} \%$ (average $8.1 \mathrm{wt} \%$ ) of the material (Table 3). These values represent wt $\%$ equivalent of calcite, i.e., the amount of calcite that would cause release of the same volume of $\mathrm{CO}_{2}$ as observed in our experiments. There are no carbonates in the underlying alluvial sediments. The tailings from borehole PK8 show a comparable amount of carbonates; the minimum carbonate content in this borehole was discussed above.

The carbonate content could be used to predict whether the tailings can or cannot develop acidic waters, that is, to answer the question if the carbonates will be exhausted before all pyrite decomposes. The answer is not simple because the chemically analyzed amount of $\mathrm{Fe}$ does not originate only from pyrite; other sources of Fe are the sulfides arsenopyrite, berthierite and gudmundite, the silicates (amphiboles, chlorites), Fe-dolomite and iron oxides. Optical examination gave a better estimate of the abundance of pyrite although it is certain that some pyrite was washed out with the lighter minerals during the preparation of the heavy mineral concentrates. A simple calculation from our experimental 
data shows, however, that even in the most favorable case for acid generation (much pyrite, little carbonate), the neutralization capacity of the carbonates exceeds the acid generation capacity of pyrite by a factor of 4 . These capacities were calculated simply as the molar ratio of $\mathrm{CO}_{2}$ from carbonates to the $\mathrm{S}$ from pyrite. In a typical tailings sediment from Pezinok, the neutralization capacity exceeds the acid generation capacity by a factor of 100 or more. Therefore, the tailings from this locality will not develop acid-mine drainage even if all pyrite were to decompose to sulfuric acid and iron oxides.

\subsection{Arsenic and antimony budget of the impoundments}

The two impoundments hold a total of $5,740 \times 10^{3} \mathrm{~kg}$ As and $6,360 \times 10^{3} \mathrm{~kg}$ of Sb. These values were calculated from the analyses of the material recovered from the boreholes. The area of the impoundments was deduced from aerial photographs and multiplied by the thickness of each sampled layer from the boreholes to determine the volume of each layer. It was assumed that the layers are laterally homogeneous and that the areas of all layers in one impoundment are equal. The mass of each layer was calculated from the measured density values for borehole PK7 (Table 3). The average bulk density is $1.56 \pm 0.16(1 \sigma) \mathrm{g} \cdot \mathrm{cm}^{-3}$, while the average particle density is $2.90 \pm 0.20(1 \sigma) \mathrm{g} \cdot \mathrm{cm}^{-3}$. The porosity of the tailings is $45 \pm 4(1 \sigma) \%$, as calculated from the bulk- and particle densities. For boreholes PK6 and PK8, where density was not experimentally measured, we have taken an average density of $1.56 \mathrm{~g} \cdot \mathrm{cm}^{-3}$. All of these estimates and assumptions contribute to systematic errors whose magnitude is difficult to judge. Nevertheless, our results agree well with a similar unpublished calculations of Pomorský et al. (2002), suggesting that the assumptions made are reasonable.

\subsection{Possible courses of action and their pitfalls}

Several possible courses of action, some being remediation strategies, their advantages and disadvantages are listed in Table 7. The simplest approach is to do nothing, which seems the most likely course of events given the current economic, political and societal state of the Slovak Republic. The impoundments will release the toxic elements, contaminate the alluvial sediments downstream and create secondary reservoirs with elevated As and possibly Sb. Such secondary reservoirs already exist (Majzlan et al. 2007). The remediation of the secondary reservoirs is virtually impossible unless new technologies (e.g. based on microbial action targeted to As) are developed.

A possible remediation strategy is the binding of the arsenic to freshly precipitated hydrous ferric oxide (HFO). The HFO could be produced by oxidation of iron scrap in a barrier through which the contaminated water would flow. The application of HFO as a cleanup agent for arsenic-contaminated waters is a standard technology, used for example in the city of Los Angeles (Root et al. 2007) or to clean heavily-polluted water for drinking in south-eastern Asia (Ahmed 2001). Simonic (2009) reported that the As content of $\alpha-\mathrm{FeOOH}$ used for remediation reaches up to $12.5 \mathrm{mg} \mathrm{As}{ }^{5+}$ per gram of $\alpha-\mathrm{FeOOH}$ (i.e. a molar $\mathrm{Fe} / \mathrm{As} \sim 67)$. Fresh HFO used to clean the water for Los Angeles has molar Fe/As values between 100-200 (Root et al. 2007). Domestic units used in villages in Bangladesh produce As-contaminated $\mathrm{HFO}$ with $\mathrm{Fe} / \mathrm{As}$ (molar) values of 14-150 (calculated from data 
in Ali et al. 2001). These values, typical for the HFO produced in water cleanup facilities, would mean that the amount of HFO to be safely disposed of would reach 340,000 tons (for a conservative $\mathrm{Fe} / \mathrm{As}$ estimate of 70). It is striking that, according to our calculations, the smaller, upper impoundment at Pezinok holds approximately 190,000 tons of tailings. Therefore, treatment of the entire volume of the present-day tailings would generate a medium-sized impoundment which would have to be safely isolated from rain and surface water.

TABLE 7

Advantages and disadvantages of possible courses of action

\begin{tabular}{ccc}
\hline Course of action & Advantages & Disadvantages \\
\hline No action & No cost & $\begin{array}{c}\text { Arsenic and antimony will be } \\
\text { further released into the } \\
\text { environment }\end{array}$ \\
\hline $\begin{array}{c}\text { Active barrier and binding } \\
\text { of As to HFO }\end{array}$ & $\begin{array}{c}\text { Arsenic will not be released into } \\
\text { the environment as long as the } \\
\text { barrier is maintained }\end{array}$ & $\begin{array}{c}\text { Needs continued investment. } \\
\text { Needs monitoring of the barrier } \\
\text { and safe disposal of the As-rich } \\
\text { HFO }\end{array}$ \\
\hline $\begin{array}{c}\text { Isolation of impoundment } \\
\text { from water flow (rain, } \\
\text { surface- and ground water) }\end{array}$ & $\begin{array}{c}\text { No elements will be released from } \\
\text { the impoundment as long as the } \\
\text { isolation systems are intact }\end{array}$ & $\begin{array}{c}\text { May require large initial } \\
\text { investment }\end{array}$ \\
\hline $\begin{array}{c}\text { Exploitation of the } \\
\text { impoundments } \\
\text { as a source of raw } \\
\text { materials (Sb) }\end{array}$ & $\begin{array}{c}\text { In certain circumstances, may } \\
\text { produce profit and generate jobs. } \\
\text { Resulting waste may be deposited } \\
\text { in an environmentally more } \\
\text { friendly manner }\end{array}$ & $\begin{array}{c}\text { Companies may not accept } \\
\text { liability for the pre-existing toxic } \\
\text { waste }\end{array}$ \\
\hline
\end{tabular}

We have recently shown (Majzlan et al. 2011) that a limiting molar Fe/As value for the As-rich hydrous ferric oxide is 2 . Beyond this ratio, HFO does not hold any more arsenic. Therefore, in a case where this extreme ratio was achieved, one could expect $\sim 10,000$ metric tons of As-rich HFO as a product of the remediation effort. All this material would have to be deposited in a manner safer than the current mode of deposition. Achieving the limiting Fe/As value, however, would mean that the material would be prone to release As which is not desirable.

The isolation of the impoundments from water flows, be they rain, surface- or ground water, is yet another possibility. As mentioned above, the impoundments are covered by industrial waste. This waste, however, does not isolate the tailings from water and provides no protection against water penetration or release. The hydrogeological research carried out by our team (Chovan et al. 2006) may form a basis for the design of passive barriers which would isolate the impoundments from the surface and ground waters.

A tempting possibility would be to consider the impoundments as a source of raw materials, for example Sb. There would be no need to mine and grind the ores. It is therefore instructive to compare the antimony budget of the impoundments to the amount of this element recovered in the Pezinok deposit itself and elsewhere in Slovakia. 
Koděra et al. (1990) and Beránek (1977) estimated that the Pezinok deposit produced about 6,500 metric tons of antimony during 1946-1974 (249 tons of Sb per year). During 1975-1991, the deposit produced about 8,000 tons of Sb (Tapak et al. 1990). Altogether, the deposit delivered about 14,500 tons of Sb between 1946 and 1991, a value comparing well with the present estimate of the antimony content in the impoundments.

A significantly larger deposit at Dúbrava (Fig. 1, inset) delivered 22,000 metric tons of antimony during 1944-1991, ranking this deposit among the largest producers in the world at that time (Arvensis et al. 1994). A smaller deposit in Poproč (Fig. 1, inset) produced about 10,800 metric tons of antimony during 1931-1965.

Given these values, more than 6,000 tons of $\mathrm{Sb}$ in the impoundments in Pezinok may be of economic interest in the future if the demand for antimony does not diminish and the price increases. However, the recovery of $\mathrm{Sb}$ from these tailings may be difficult because the separation by flotation is preferentially effective for sulfidic ores (Wills 2008). The impoundments contain a large fraction of the $\mathrm{Sb}$ in the form of oxides, either as relatively pure Sb oxides or more commonly as Fe-Sb oxides (Majzlan et al. 2011). Separation of these oxides from silicates and carbonates may be difficult owing to their similar surface properties (Wills 2008, p. 270). Indeed, the presence of Sb in oxide minerals in Pezinok was recognized as a significant hindrance to $\mathrm{Sb}$ recovery from these ores by flotation (Grexová 1991). Other forms of separation, e.g. chemical, pyrometallurgical or hydrometallurgical, may be too expensive or environmentally unfriendly.

Another question related to the remediation effort is the gold content of the tailings. If high enough, an industrial reuse of the tailings would be a viable option, and the deposition of the remaining waste could be much better planned. With a significant analytical effort, the gold content could be measured just as the content of $\mathrm{Fe}$, As and $\mathrm{Sb}$ was. Instead, here we present an estimate of the total gold budget.

The two impoundments contain a total of 5,740 metric tons of As (Table 1). In a recent study of Au-bearing arsenopyrite from Pezinok, Majzlan et al. (2010) determined that arsenopyrite from Pezinok contains $44.5 \mathrm{wt} \%$ of As. Most of the As in the ores is present in arsenopyrite, although subordinate quantities may be found in pyrite and löllingite. Neglecting pyrite and löllingite, the impoundments should have received an input of 12,900 metric tons of arsenopyrite. The arsenopyrite crystals studied by Majzlan et al. (2010) contained $10.2 \mathrm{ppm} \mathrm{Au}$. If this is the average content, the impoundments would contain $132 \mathrm{~kg}$ gold, too little for a potential future exploitation.

\section{Conclusions}

The two impoundments in Pezinok contain a significant amount of As and $\mathrm{Sb}$ (Table 1). Any remediation strategy has to take this amount into account and evaluate its short-term and long-term gains and risks. The most likely course of action, mostly owing to financial constraints, is to do nothing. Although this action costs nothing in the short term, it may result in significant damage to the environment, especially to the alluvial sediments and the associated water resources in the long term. If the financial constraints were to be lifted, the best strategy would probably be isolation of the impoundments from rain and ground water. A similar conclusion can be likely drawn for all comparable impoundments 
of former- or active $\mathrm{Sb}$ deposits where the tailings are near-neutral and contain a significant amount of As.

Acknowledgements. We thank M. Bach and an anonymous reviewer for helpful critical comments and M. Michalik for the editorial handling of the manuscript. The AAS analyses of the tailings were done by S. Hirth-Walther (Freiburg) and the carbonate analyses by T. Wach (Jena). This study was financially supported by the Wissenschaftliche Gesellschaft in Freiburg im Breisgau, Deutsche Forschungsgemeinschaft, grant no. MA 3927/6-1 and the Slovak Research and Development Agency, grant. no. APVV-0268-06, VVCE-0033-07.

\section{References}

Ahmed, M.F. (2001). An overview of arsenic removal technologies in Bangladesh and India. Proceedings of the BUET-UNU International Workshop on Technologies for Arsenic Removal from Drinking Water, Bangladesh University of Engineering and Technology, Dhaka, Bangladesh.

Ali, M.A., Badruzzaman, A.B.M., Jalil, M.A., Hossain, M.D., Hussainuzzaman, M.M., Badruzzaman, M., Mohammad, O.I., \& Akter, N. (2001). Development of low-cost technologies for removal of arsenic from groundwater. Proceedings of the BUET-UNU International Workshop on Technologies for Arsenic Removal from Drinking Water, Bangladesh University of Engineering and Technology, Dhaka, Bangladesh.

Arvensis, M., Tupý, P., Kupcová, Z., Fodorová, V., Mudráková, M., Čechovská, K., Čamaj, P., \& Klačan, J. (1994). Dúbrava - tailings, preliminary research. Manuskript - Geologický prieskum Spišská Nová Ves, 188 pp. (in Slovak)

Beránek, M. (Ed.) (1977). $30^{\text {th }}$ anniversary of Rudné bane Banská Bystrica. Martin: Osveta. (in Slovak)

Chovan, M., Andráš, P., Čerňanský, S., Dlapa, P., Fl’aková, R., Hudáček, M., Krčmář, D., Kušnierová, M., Lalinská, B., Lux, A., Majzlan, J., Milovská, S., Moravanský, D., Ševc, J., Šimonovičová, A., Šlesárová, A., Šottník, P., Uhlík, P., Urík, M., \& Ženišová, Z. (2006). Determination of the contamination risk in the vicinity of the $S b, A u, S$ deposit Pezinok and a proposal for remediation: Toxicity of As, Sb, and acidification. Bratislava: Comenius University (Project no. AV/901/2002 (VTP25), final report) (in Slovak)

Filippi, M., Goliáš, V., \& Pertold, Z. (2004). Arsenic in contaminated soils and anthropogenic deposits at the Mokrsko, Roudný, and Kašperské Hory gold deposits, Bohemian Massif (CZ). Environmental Geology, 45, 716-730.

Flaková, R., Ženišová, Z., Drozdová, Z., \& Milovská, S. (2005). Distribution of arsenic in surface and groundwater in Kolársky vrch mining area (Malé Karpaty Mts.). Podzemná Voda, 9, 90-103. (in Slovak with English summary)

Grexová, A. (1991). Mineralogy of the technological products at the Sb deposit Pezinok. Unpublished Diploma thesis, Comenius University, Bratislava. (in Slovak)

Heikkinen, P.M., Räisänen, M.L., \& Johnson, R.H. (2009). Geochemical characterisation of seepage and drainage water quality from two sulphide mine tailings impoundments: Acid mine drainage versus neutral mine drainage. Mine Water and the Environment, 28, 30-49.

Koděra, M., Andrusovová-Vlčeková, G., Belešová, O., Briatková, D., Dávidová, Š., Fejdiová, V., Hurai, V., Chovan, M., Nelišerová, E., \& Ženiš, P. (1990). Topographic mineralogy of Slovakia, Band 2. Bratislava: Veda, vyd. Slovenskej akadémie vied.

Lindsay, M.B.J., Condon, P.D., Jambor, J.L., Lear, K.G., Blowes, D.W., \& Ptacek, C.J. (2009). Mineralogical, geochemical and microbial investigation of a sulfide-rich tailings deposit characterized by neutral drainage. Applied Geochemistry, 24(12), 2212-2221. DOI: 10.1016/j.apgeochem.2009.09.012

Loredo, J., Ordónez, A., Baldo, C., \& García-Iglesias, J. (2003). Arsenic mobilization from waste piles of the El Terronal mine, Asturias, Spain. Geochemistry: Exploration, Environment, Analysis, 3, 229-237.

Majzlan, J., Lalinská, B., Chovan, M., Jurkovič, L., Milovská, S., \& Göttlicher, J. (2007). The formation, structure, and ageing of As-rich hydrous ferric oxide at the abandoned Sb deposit Pezinok (Slovakia). Geochimica Cosmochimica Acta, 71, 4206-4220.

Majzlan, J., Chovan, M., Andráš, P., Newville, M., \& Wiedenbeck, M. (2010). The nanoparticulate nature of invisible gold in arsenopyrite from Pezinok (Slovakia). Neues Jahrbuch für Mineralogie Abhandlungen, 187, $1-9$ 
Majzlan, J., Lalinská, B., Chovan, M., Bläß, U., Brecht, B., Göttlicher, J., Steininger, R., Hug, K., Ziegler, S., \& Gescher, J. (2011). A mineralogical, geochemical, and microbiogical assessment of the antimony- and arsenic-rich neutral mine drainage tailings near Pezinok, Slovakia. American Mineralogist, 96(1), 1-13. DOI: 10.2138/am.2011.3556

Moldovan, B.J., \& Hendry, M.J. (2005). Characterizing and quantifying controls on arsenic solubility over a pH range of 1-11 in a uranium mill-scale experiment. Environmental Science \& Technology, 39, 4913-4920.

Moravanský, D., Chovan, M., \& Lipka, J. (2001). Phyllosilicates from hydrothermally altered granitoid rocks in the Pezinok Sb-Au deposit, Western Carpathians, Slovakia. Geologica Carpathica, 52, 127-138.

Moore, D.M., \& Reynolds, R.C. (1997). X-Ray Diffraction and the Identification and Analysis of Clay Minerals (2 ed.). New York: Oxford University Press, USA.

Paktunc, D., Foster, A., \& Laflamme, G. (2003). Speciation and characterization of arsenic in Ketza River mine tailings using X-ray absorption spectroscopy. Environmental Science \& Technology, 37, 2067-2074.

Pomorský, F., Hanas, P., Mokráš, L., Bendíková, Z., \& Stašík, L. (2002). Complex evaluation of the closed deposit Pezinok. Bratislava, Slovakia: Ministry of the Environment of the Slovak Republic. (in Slovak)

Rauret, G., López-Sánchez, J.F., Sahuquillo, A., Rubio, R., Davidson, C., Ure, A., \& Quevauviller, P. (1999). Improvement of the BCR three step sequential extraction procedure prior to the certification of new sediment and soil reference materials. Journal of Environmental Monitoring, 1, 57-61.

Root, R.A., Dixit, S., Campbell, K.M., Jew, A.D., Hering, J.G., \& O'Day, P.A. (2007). Arsenic sequestration by sorption processes in high-iron sediments. Geochimica et Cosmochimica Acta, 71, 5782-5803.

Simonic, M. (2009). Removal of inorganic $\mathrm{As}^{5+}$ from a small drinking water system. Journal of the Serbian Chemical Society, 74, 85-92.

Suter II, G.W., \& Tsao, C.L. (1996). Toxicological Benchmarks for Screening Potential Contaminants of Concern for Effects on Aquatic Biota. 1996 Revision. Oak Ridge, Tennessee: Oak Ridge National Laboratory. (ES/ER/TM-96/R2; http://www.hsrd.ornl.gov/ecorisk/tm96r2.pdf)

Tapak, M., Kiripolský, J., Richter, S., \& Slavkovská, M. (1990). Geological reserves of ore deposits of the Slovak Republic as of January 1, 1990. Bratislava: Geofond Bratislava. (in Slovak)

Wills, B.A. (2008). Wills’ Mineral Processing Technology (7 ed.). Oxford: Butterworth-Heinemann. 